\title{
中国地域における食品工業の農業への波及効果分析
}

\author{
佐藤 淳基 (鳥取大学大学院農学研究科) \\ 万里 (鳥取大学農学部)
}

\section{Analyzing the Ripple Effect of the Food Industry on Agricultural Production in the Chugoku Region}

\author{
Junki Sato (Graduate School of Agriculture, Tottori University) \\ Li Wan (Faculty of Agriculture, Tottori University)
}

This paper examined the ripple effect of the food industry on agricultural production in the Chugoku region, Japan, on the basis of an input-output analysis. The following results were obtained: (1) The ripple effect of the food industry on agricultural production in this region is not as significant as it is in other regions. (2) The effect of the rice milling and alcoholic beverage sectors on agricultural production is more significant in this region than in other

\section{1. はじめに}

食品工業と農業は原材料の需要・供給といら面で 密接に結びついており, 食品工業の生産額変動は農 業生産額へ影響を与える. 全世帯を対象とした食料 消費支出割合の変化 [3] を見ると，1970 年では食料 消費支出の 5 割を生鮮食料品が占めていたが，2005 年では 3 割程度まで減少し, 逆に加工食品, 外食産 業などの消費支出割合が高まった。農産品の食品工 業を通じた食料消費の進展から, 地域農業の発展を 考光るらえで, その仕向先である食品工業との相互 依存関係を把握することは重要な課題であると考兄 られる, そこで, 本研究では, 食品工業の地域農業 への効果を定量的に把握し, 中国地域に打情品 工業を通じた農業生産動向について考察を行うこと を目的とする.

食品工業と農業との相互依存関係に関する既存研究 では, 薬師寺 [4] が特定部門の生産変動が農業, 地 域経済に与える効果を分析し, 上路 [1] は食品工業 全般を対象とし, 輸入原材料の価格高騰による影響を 明らかにした。また，倉知 [2] は地域農業と地域食品 工業に焦点を当て, 九州・沖縄地域の各食品工業部門 の生産額が増加した場合の地域農業生産への効果を分 regions. (3) The effect of the livestock, rice milling, and cooked food sectors on agricultural production occupies the bigger share than other sectors. (4) In the food industry in this region, the dependence on other regions for raw materials is relatively high. (5) The effects of the production values of the livestock, rice milling, and cooked food sectors on the agricultural production value have decreased.

析した，本研究では，これまで研究成果に例がない中 国地域各食品工業を対象とし，他地域との比較分析も 併せたらえで考察を行う，具体的には，産業連関表を 用いて逆行列係数表を作成し, 各食品工業部門と農業 との相互依存関係を把握した．逆行列係数は，ある部 門の最終需要の変化に伴う他部門への生産誘発額を求 めるために用いられるが，ここでは，各食品工業部門 の生産額そのものの変化に伴う効果を調べるため, 逆 行列係数表の各食品工業部門に括いて簡略計算法を用 いて外生化 ${ }^{1)}$ 行った。 また，外生化した逆行列係数 を生産波及係数 ${ }^{2)}$ と呼び，そして生産額と生産波及係 数を乗じることで求められる波及額を生産波及額と呼 ぶこととする。 また，逆行列係数には，地域内生産品 と移輸入品を区別する開放経済型とそ机らの区別をし ない閉鎖経済型の 2 つ型があるが，本研究では，中 国地域食品工業の地域農業への効果を把握するといら 分析の性質上，地域内生産品と移輸入品を分けて扱引 必要があるため, 開放経済型逆行列を用いて生産波及 係数を算出した.

\section{2. 食品工業部門別比較}

ここでは，総務省統計局発行の接続産業連関表 
（7-12-17 年）を用いて部門別に，生産額（表 1)，農 業への生産波及係数（表 2), 生産波及額（表 3）の 推移をまとめた。

生産額を見ると, 平成 17 年では, めん・パン・ 菓子類, その他飲料, その他食料品, 酒類, 調理済 食品の順に大きい值となっている. その他飲料, 調 理済食品, めん・パン・菓子類が生産額を伸ばす一 方で, 酒類, 水産食料品の生産額の落ち込みが激し く, 近年の外食, 中食の増加なぞ, ライフスタイル の変化によるものと考光られる.

生産波及係数を見ると，平成 17 年では，精穀，

表 1. 食品工業別生産額の推移

\begin{tabular}{|c|c|c|c|c|}
\hline 生産額（百億円） & 平成 7 年 & 平成 12 年 & 平成 17 年 & 変化額 \\
\hline 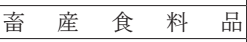 & 293 & 292 & 278 & -15 \\
\hline $\begin{array}{llll}\text { 水 産 } & \text { 食 } & \text { 料 } \text { 品 } \\
\end{array}$ & 409 & 349 & 322 & -87 \\
\hline 精 & 277 & 283 & 259 & -17 \\
\hline & 56 & 55 & 54 & -1 \\
\hline めん・パン・菓子類 & 467 & 471 & 475 & 8 \\
\hline 農産保存食料品 & 66 & 67 & 58 & -9 \\
\hline 砂糖 - 油脂 - 調味料類 & 254 & 265 & 262 & 8 \\
\hline 調 理 済 食 品 & 286 & 329 & 337 & 51 \\
\hline 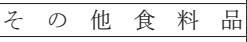 & 370 & 417 & 373 & 4 \\
\hline & 457 & 431 & 347 & -109 \\
\hline そ の 他 飲 料 & 355 & 412 & 451 & 96 \\
\hline
\end{tabular}

\section{表 2. 食品工業別生産波及係数の推移}

\begin{tabular}{|c|c|c|c|c|}
\hline 生産波及係数 & 平成 7 年 & 平成 12 年 & 平成 17 年 & 変化量 \\
\hline 章 産 食 料 品 & 0.46 & 0.44 & 0.44 & -0.01 \\
\hline 産 食 料 品 & 0.01 & 0.01 & 0.01 & 0.00 \\
\hline 穀 & 0.89 & 0.78 & 0.82 & -0.07 \\
\hline 粉 & 0.25 & 0.33 & 0.36 & 0.11 \\
\hline めん・パン・菓子類 & 0.13 & 0.14 & 0.15 & 0.02 \\
\hline 農産保存食料品 & 0.24 & 0.20 & 0.23 & -0.01 \\
\hline 砂糖 - 油脂 - 調味料類 & 0.12 & 0.12 & 0.11 & -0.01 \\
\hline 調 理 済 食 品 & 0.30 & 0.28 & 0.31 & 0.01 \\
\hline そ の 他 食 料 品 & 0.14 & 0.19 & 0.23 & 0.08 \\
\hline 酒 & 0.06 & 0.05 & 0.06 & -0.01 \\
\hline 他 飲 料 & 0.07 & 0.05 & 0.05 & -0.02 \\
\hline
\end{tabular}

表 3. 食品工業別生産波及額の推移

\begin{tabular}{|c|c|c|c|c|}
\hline 生産波及額（百億円） & 平成 7 年 & 平成 12 年 & 平成 17 年 & 変化額 \\
\hline $\begin{array}{llll}\text { 畜 産 } & \text { 食 } & \text { 料 } \\
\end{array}$ & 134 & 128 & 123 & -11 \\
\hline $\begin{array}{llll}\text { 水 産 食 料 品 } \\
\end{array}$ & 4 & 3 & 3 & -2 \\
\hline 穀 & 247 & 220 & 212 & -34 \\
\hline 粉 & 14 & 18 & 20 & 6 \\
\hline めん・パン・菓子類 & 61 & 67 & 70 & 10 \\
\hline 農産保存食料品 & 16 & 14 & 13 & -3 \\
\hline 砂糖・油脂・調味料類 & 31 & 31 & 30 & -2 \\
\hline $\begin{array}{llll}\text { 調 理 済 食 品 } \\
\end{array}$ & 86 & 93 & 105 & 18 \\
\hline そ の 他 食 料 品 & 20 & 25 & 31 & 11 \\
\hline 類 & 28 & 22 & 20 & -9 \\
\hline $\begin{array}{lllll} & \text { の } & \text { 他 } & \text { 飲 } \\
\end{array}$ & 25 & 22 & 22 & -3 \\
\hline
\end{tabular}

畜産食料品, 製粉, 調理済食品の順で大きい值であっ た. 生産波及係数は，製造コストに占める原材料投 入額の割合（投入係数）と原材料の移輸入の割合に 影響を受けるが，精穀は原材料投入額の割合が高い ことに加え，移輸入の割合が低いため，最も高い生 産波及係数を示す結果となった。 また, 畜産食料品, 製粉に関しては原材料投入額の割合が高く，調理済 食品に関しては移輸入の割合が低いことが，生産波 及係数が高い主な原因であると分析できる.

生産波及額を見ると，平成 17 年では，精穀，畜産 食料品, 調理済食品, めん・パン・菓子類の順で大 きい額となっているが，畜産食料品は平成 7 年に比 ベ減少し，一方調理済食品，めん・パン・菓子類は 増加するなど, 近年の食品工業生産の変化が農業生 産に影響を与えていることが分かる。

\section{3. 食品工業の地域間比較}

中国地域食品工業が他地域食品工業と比較して, どのよらな特徵があるかを把握するため，各地域の 経済産業局から発行された平成 17 年地域産業連関 表を用いて，全国を9 地域に分けて比較分析を行っ た. 図 1 から分かるよらに，食品工業の生産額は関 東地域が最も大きく，約 13 兆円であり，2 位であ る近畿地域の約 5 兆 3,000 億円より 2 倍以上の差が あった. 一方, 中国地域食品工業の生産額は小さく, 沖縄，四国に次ぐ下から 3 番目であり，1 兆 6,000 億 円汪どとなっている．生産波及係数については，最 も大きいのが北海道の 0.21 , 中国地域は 0.14 となっ て颃り, 全国で 5 番目の順位に位置している。 また, 関東，中部，近畿などの大都市圏は生産波及係数が 低い值となっている。ささらに，生産波及額は，生産 額が大きかった関東地域が最も大きく 1 兆 7,000 億 円ほど，中国地域は2,263 億円と低い值であり，全国

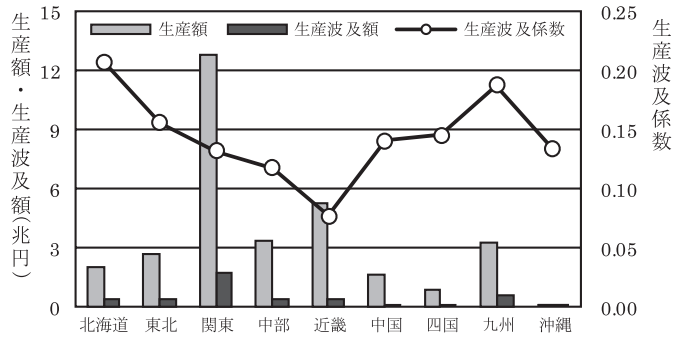

図 1. 食品工業の地域別比較

注：平成 17 年各地域産業連関表により作成した. 
表 4. 各地域食品工業部門別生産波及係数

\begin{tabular}{|c|c|c|c|c|c|c|c|c|c|c|}
\hline & 北海道 & 東北 & 関東 & 中部 & 近畿 & 中国 & 四国 & 九州 & 沖縄 & 平均値 \\
\hline 畜 産 食 料 品 & 0.510 & 0.369 & 0.245 & 0.236 & 0.099 & 0.269 & 0.340 & 0.400 & 0.415 & 0.320 \\
\hline 水 産 食 料 品 & 0.002 & 0.004 & 0.004 & 0.003 & 0.002 & 0.004 & 0.003 & 0.004 & 0.015 & 0.005 \\
\hline 精 & 0.466 & 0.683 & 0.584 & 0.521 & 0.390 & 0.713 & 0.560 & 0.604 & 0.036 & 0.506 \\
\hline 製 & 0.319 & 0.099 & 0.127 & 0.127 & 0.077 & 0.130 & 0.099 & 0.301 & 0.006 & 0.143 \\
\hline めん・パン・菓子類 & 0.094 & 0.039 & 0.052 & 0.037 & 0.023 & 0.037 & 0.035 & 0.080 & 0.062 & 0.051 \\
\hline 農 産 保 存 食 料 品 & 0.177 & 0.153 & 0.126 & 0.098 & 0.067 & 0.066 & 0.136 & 0.207 & 0.123 & 0.128 \\
\hline 砂糖 - 油脂 - 調味料類 & 0.320 & 0.055 & 0.057 & 0.027 & 0.025 & 0.037 & 0.050 & 0.082 & 0.512 & 0.129 \\
\hline 調 理 済 食 品 & 0.180 & 0.215 & 0.155 & 0.140 & 0.081 & 0.170 & 0.172 & 0.256 & 0.147 & 0.168 \\
\hline そ の 他 食 料 品 & 0.170 & 0.039 & 0.055 & 0.071 & 0.033 & 0.063 & 0.162 & 0.065 & 0.109 & 0.085 \\
\hline 酒 & 0.018 & 0.040 & 0.024 & 0.020 & 0.032 & 0.043 & 0.031 & 0.035 & 0.009 & 0.028 \\
\hline そ の 他 飲 料 & 0.028 & 0.016 & 0.023 & 0.008 & 0.010 & 0.013 & 0.011 & 0.029 & 0.030 & 0.019 \\
\hline
\end{tabular}

注 : 平成 17 年地域産業連関表より算出した.

で下から三番目に位置している.

表 4 では地域ごとに食品工業部門別の生産波及係 数をまとめた. 北海道, 九州地域に抢いては比較的 高い値を示す部門が多い。一方, 中国地域では精穀, 調理済食品, 酒類に执いて平均值以上が見られた. しかし, 酒類の生産波及係数の值が他の部門に比べ て小さく, 農業への波及効果はあまり期待できない. また，それ以外の部門では全国平均に近いか，それ 以下の数值を示して打り, 中国地域では地域の農産 物を活かした食品工業部門が他地域よりも少ないこ とが明らかである。

以上のことから, 現状に敃いては中国地域食品工 業の生産額増加は地域農業の生産額増加に結び付き にくいと考えられる.

\section{4. 中国地域食品工業の農業への波及効果}

中国地域食品工業の近年の動向及び農業への波及 効果を解明するため, 中国経済産業局が発行した中 国地産業連関表（平成 12 年, 平成 17 年）を用いて 分析を行った。

\section{（1）中国地域における基幹食品工業部門}

表 5 は中国地域食品工業の地域農業への生産波及 額と食品工業部門ごとの構成比を示した. 平成 12 年から平成 17 年にかけて, すべての食品工業部門 の生産波及額は減少した。構成比を見ると, 平成 17 年では精穀, 酒類が平成 12 年より増大したもの の, それ以外の部門では減少した。 また, 平成 17 年 に扣いては，精穀の構成比は $51.5 \%$ と最も大きく, 畜産食料品, 調理済食品の生産波及額と合わせると 8 割以上を占めて扣り, この 3 部門の生産動向が中
国地域農業へ与える影響は大きいと考えられる.

\section{（2）生産波及係数変化の要因}

中国地域農業へ大きく影響を与えると考えられる 畜産食料品，精穀，調理済食品に焦点を当て，平成 12 年から平成 17 年までの生産波及係数の推移(表6) を見ると，これら 3 部門に関しては，どれも 1 割程 度の変化が見られた．生産波及係数の増減には，原 材料の移輸入の割合と製造コストに占める原材料投 入額の割合が影響している.

また，移輸入の影響を調べるために域外流出率 ${ }^{3)}$ を計測して表 7 によとた。畜産食料品，調理済食 品は域外流出率が平成 17 年は平成 12 年に比べて増 加して扣り，これはこの 2 部門に打ける原材料の他 地域への依存を強めたと考えることができる. 一方, 精穀は域外流出率が減少しており，移輸入の割合が 減少したと考えられる.

製造コストに占める原材料投入額の割合の変化を

\section{表 5. 生産波及額の構成比}

\begin{tabular}{|c|c|c|c|c|c|c|}
\hline & \multicolumn{3}{|c|}{ 生産波及額(億円) } & \multicolumn{3}{|c|}{ 構成比(\%) } \\
\hline & 平成 12 年 & 平成 17 年 & 変化額 & 平成 12 年 & 平成17年 & 変化量 \\
\hline 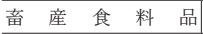 & 607 & 368 & -239 & 18.2 & 16.3 & -1.9 \\
\hline 水 産 食 料 品 & 14 & 10 & -4 & 0.4 & 0.4 & 0.0 \\
\hline 穀 & 1,400 & 1,166 & -234 & 41.9 & 51.5 & 9.6 \\
\hline 粉 & 80 & 26 & -54 & 2.4 & 1.1 & -1.3 \\
\hline めん・パン・菓子類 & 216 & 83 & -133 & 6.5 & 3.7 & -2.8 \\
\hline 農産保存食料品 & 62 & 23 & -39 & 1.9 & 1.0 & -0.8 \\
\hline 砂糖 - 油脂 - 調味料類 & 150 & 58 & -92 & 4.5 & 2.6 & -1.9 \\
\hline 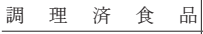 & 487 & 325 & -162 & 14.6 & 14.4 & -0.2 \\
\hline その他の食料品 & 224 & 132 & -92 & 6.7 & 5.8 & -0.9 \\
\hline 類 & 59 & 58 & -1 & 1.8 & 2.6 & 0.8 \\
\hline その他 の 飲 料 & 38 & 14 & -24 & 1.1 & 0.6 & -0.5 \\
\hline 合 計 & 3,336 & 2,263 & $-1,073$ & 100.0 & 100.0 & 0.0 \\
\hline
\end{tabular}


表 6. 中国地域食品工業の生産波及係数

\begin{tabular}{|c|c|c|c|}
\hline 生産波及係数 & 平成 12 年 & 平成 17 年 & 変化量 \\
\hline $\begin{array}{llll}\text { 畜 産 食 料 品 } \\
\end{array}$ & 0.40 & 0.27 & -0.13 \\
\hline 水 産 食 料 品 & 0.004 & 0.004 & 0.00 \\
\hline 精 & 0.60 & 0.71 & 0.11 \\
\hline 製 & 0.30 & 0.13 & -0.17 \\
\hline めん・パン・菓子類 & 0.08 & 0.04 & -0.04 \\
\hline 農 産 保存 食料品 & 0.21 & 0.07 & -0.14 \\
\hline 砂糖 - 油脂 - 調味料類 & 0.08 & 0.04 & -0.05 \\
\hline 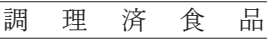 & 0.26 & 0.17 & -0.09 \\
\hline そ の 他 食 料 品 & 0.06 & 0.06 & 0.00 \\
\hline 酒 & 0.04 & 0.04 & 0.01 \\
\hline そ の 他 飲 料 & 0.03 & 0.01 & -0.02 \\
\hline
\end{tabular}

注: 平成 12 年, 平成 17 年中国産業連関表による.

表 7. 域外流出率の推移

\begin{tabular}{|c|c|c|c|}
\hline 単位（\%) & 平成 12 年 & 平成 17 年 & 変化量 \\
\hline $\begin{array}{llll}\text { 畜 産 食 料 品 } \\
\end{array}$ & 29 & 43 & 14 \\
\hline 水 産 食 料 品 & 91 & 80 & -11 \\
\hline 穀 & 26 & 16 & -10 \\
\hline 粉 & 60 & 83 & 23 \\
\hline めん・パン・菓子類 & 77 & 86 & 9 \\
\hline 農 産保存食料品 & 35 & 76 & 41 \\
\hline 砂糖・油脂・調味料類 & 86 & 80 & -6 \\
\hline $\begin{array}{llll}\text { 琱 理 食 品 } \\
\end{array}$ & 42 & 58 & 16 \\
\hline そ の 他 食 料 品 & 77 & 60 & -16 \\
\hline 類 & 58 & 38 & -19 \\
\hline $\begin{array}{lllll}\text { そ } & \text { の } & \text { 他 } & \text { 飲 } & \text { 料 } \\
\end{array}$ & 68 & 87 & 18 \\
\hline
\end{tabular}

注 : 平成 12 年, 平成 17 年中国産業連関表による.

表 8. 投入係数の推移

\begin{tabular}{|c|c|c|c|}
\hline & 平成 12 年 & 平成 17 年 & 変化量 \\
\hline $\begin{array}{llll}\text { 畜 産 食 料 品 } \\
\end{array}$ & 0.311 & 0.312 & 0.001 \\
\hline 水 産 食 料 品 & 0.004 & 0.005 & 0.001 \\
\hline 穀 & 0.781 & 0.732 & -0.049 \\
\hline 製 & 0.360 & 0.513 & 0.153 \\
\hline めん・パン・菓子類 & 0.017 & 0.019 & 0.002 \\
\hline 農 産保存 食料品 & 0.233 & 0.236 & 0.002 \\
\hline 砂糖 - 油脂 - 調味料類 & 0.115 & 0.136 & 0.022 \\
\hline 調 理 済 食 品 & 0.113 & 0.108 & -0.005 \\
\hline そ の 他 食 料 品 & 0.093 & 0.100 & 0.007 \\
\hline 酒 & 0.033 & 0.028 & -0.005 \\
\hline そ の 他 飲 料 & 0.035 & 0.055 & 0.019 \\
\hline
\end{tabular}

注：平成 12 年, 平成 17 年中国産業連関表による.

把握するため，投入係数の変化を表 8 によとめ. これを見ると, 畜産食料品で増加, 精穀, 調理済食 料品で減少したことが分かった。しかし，いずれの 投入係数の変化量も非常に小さく，生産波及係数に はあまり大きな影響を与えないと考えられる。
よって，畜産食料品，精穀，調理済食品部門にお ける生産波及係数の变化は移輸入の割合の变化が主 な原因と考兄らる。

\section{（3）各仕向額と移輸入・移輸出の推移}

平成 12 年から平成 17 年への中国地域に打辇る食 品工業全体の生産額は内生需要, 民間消費支出とも に 1 割程度減少し, 移輸出も 2 割程度減少する一方 で，移輸入は微増した（表 9)。これは，中国地域 食品工業の地域内シェアが他地域に奪われたためと 考兄られる。畜産食料品, 精穀, 調理済食品に着目 すると，畜産食料品は移輸出と移輸入がともに増加 し，全体としては生産額が微増した。精穀は内生需 要，民間消費支出ともに減少しており，特に移輸出 が 5 割も減少し，移輸入が 4 割程度増加したことが 目立ち，他地域にシェアを奪われる結果となった. 調理済食品は全国的に生産額が増加傾向にあるな か，中国地域ではすべての項目において減少してお り，移輸入も大きく減少していることから，中国地 域に打ける消費量が減少していると考えられる.

以上の結果をまとめると，畜産食料品の生産額が 微増したものの，原材料の地域外依存を強めたこと から生産波及係数は減少に転じ，生産波及額の減少 につながったと考えられる。精穀は生産波及係数が 増加したが，地域内外の需要低下と移輸入の増加か ら, 今後の生産額増加は難しい. また, もともと低 かった域外流出率がさらに減少していることから, 今後の生産波及係数は頭打ちになると推測できる. 調理済食品は全国的に生産額が増加傾向にあるな か, 中国地域では地域内需要が減少し，それに加え， 原材料の地域外依存も強毛って扣り，生産波及係数 の増加はいっそう難しい.

基幹的食品工業部門の生産波及額の減少によっ て，今後の中国地域に打ける食品工業生産増加によ る地域農業生産の増加は難しいと考えられる.ただ, 畜産食料品のように，生産波及額の減少理由が，生 産額ではなく, 原材料の他地域依存にあるのならば, 地域農業と食品工業の連携強化の可能性はまた残さ れていると思われる。

\section{5. おわりに}

本研究は, 中国地域食品工業の地域農業へ与える 影響を把握し，今後の食品工業を通じた農業生産の 動向を考察するものである。分析結果から判明した 
表 9. 中国地域食品工業の仕向額の推移

\begin{tabular}{|c|c|c|c|c|c|c|c|c|}
\hline & \multicolumn{4}{|c|}{ 平成 17 年（単位: 億円） } & \multicolumn{4}{|c|}{ 平成 12 から平成 17 年までの変化率 } \\
\hline & 内生需要 & 民間消費支出 & 移輸出 & 移輸入 & 内生需要 & 民間消費支出 & 移輸出 & 移輸入 \\
\hline $\begin{array}{llll}\text { 畜 産 食 料 品 } \\
\end{array}$ & 663 & 1,068 & 557 & 952 & 1.04 & 0.92 & 1.33 & 1.28 \\
\hline 水 産 食 料 品 & 787 & 1,793 & 1,674 & 1,644 & 0.94 & 0.95 & 0.72 & 1.06 \\
\hline 精 & 546 & 972 & 317 & 211 & 0.94 & 0.80 & 0.48 & 1.43 \\
\hline 粉 & 283 & 10 & 55 & 154 & 0.69 & 0.73 & 1.52 & 0.78 \\
\hline めん・パン・菓子類 & 294 & 2,342 & 1,205 & 1,680 & 0.93 & 0.91 & 0.86 & 0.99 \\
\hline 農 産保存食料品 & 214 & 357 & 255 & 485 & 1.20 & 0.94 & 1.36 & 1.04 \\
\hline 砂糖・油脂・調味料類 & 1,117 & 569 & 1,097 & 1,226 & 0.99 & 0.90 & 0.88 & 1.01 \\
\hline 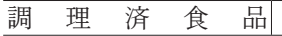 & 257 & 1,498 & 639 & 570 & 0.81 & 0.95 & 0.90 & 0.72 \\
\hline そ の 他 食 料 品 & 311 & 2,124 & 1,637 & 2,091 & 0.93 & 0.91 & 0.62 & 1.07 \\
\hline 類 & 735 & 1,245 & 636 & 1,413 & 0.95 & 0.71 & 0.98 & 0.84 \\
\hline そ の 他 飲 料 & 304 & 1,913 & 328 & 1,622 & 0.86 & 1.01 & 0.81 & 1.16 \\
\hline 食 品 工 業 全 体 & 5,511 & 13,891 & 8,401 & 12,048 & 0.94 & 0.90 & 0.79 & 1.02 \\
\hline
\end{tabular}

注 : 平成 12 年, 平成 17 年中国地域産業連関表による。

ことは以下のと扤りである。

第一に, 中国地域食品工業は他地域と比較して, 食品工業全体の地域農業への生産波及額は小さい. 第二に, 中国地域では, 精穀, 酒類の生産波及係数 が全国の平均值より高かったが，酒類に関しては全 国的に見ても生産波及効果が小さい部門であるため, 生産額の増加後も地域農業への効果は低い. 第三に, 中国地域食品工業に括いて, 畜産食料品, 精穀, 調 理済食品の 3 部門合わせると, 農業への生産波及額 の 8 割程度を占めて扣り, 重要な食品工業部門であ る. 第四に, 中国地域食品工業部門別の城外流出率 を平均すれば 60\%前後であり, 原材料の他地域依存 度が比較的に高いと思われる. 平成 17 年は平成 12 年に比べて城外流出率は部門別に増減があるものの, 全体的には増加傾向にあり, 原材料の他地域依存度 は一層強めたと考えられる. 第五に, 中国地域農業 へ大きく影響すると考学られる畜産食料品, 精穀, 調理済食品の 3 部門では地域農業への生産波及額が 減少傾向にあることから, 現状では中国地域におけ る食品工業を通じた農業生産額の増加は困難である.

本研究では, 中国地域食品工業の地域農業への波 及効果を計測したが, 今後の課題として, 中国地域 食品工業だけでなく, 他地域食品工業の生産動向に よる中国地域農業に対する波及効果も計測したい。

注 1）食品工業部門が行ら生産活動そのものが他部門へ 与える影響を計測するために, 当該部門を産業連 関表の内生部門から除外しなければならない。本 研究では簡略的な方法として, 逆行列係数表にお いて当該部門の行との交点の值で列の各数值を除
して計算した

2）生産波及係数とは, 食品工業 A で 1 単位の生産額 の変化があった場合に，原材料として投入される農 業部門の生産額がぞれほど変化するかを表した比率 である。本研究で用いた生産波及係数は，原材料と して用いられる食品工業製品の地域農業への効果も 考慮して算出した、計算方法は，例えば，食品工業 $\mathrm{A}$ の生産波及係数を求める場合は, 食品工業 $\mathrm{A}$ の食 品工業 B 対する生産波及係数と食品工業 $\mathrm{B}$ の地 域農業への生産波及係数を乗じた值を，食品工業 $\mathrm{A}$ の地域農業への生産波及係数へ付加した。

3）域外流出率とは，封鎖経済型と開放経済型の生産 波及係数の差を封鎖経済型の生産波及係数で割っ たもので，地域食品工業の農業への生産波及効果 が, 移輸入によってどれだけ地域外に流出したか を表す指標である.

\section{参考文献}

[1]上路利雄「農産物と加工食品の輸入増加が我 が国産業に及ぼす影響」『食品産業の産業組織 論的研究』農林統計協会, 2004, pp. 42-67.

[2]倉知哲朗「九州・沖縄に打ける食品工業の産 業連関分析」『九州沖縄農業研究センター報告』 第 52 号 (2009.9), pp. 95-126.

[3] 農林水産省『平成 22 年度版 食料・農業 ・農 村白書』左伯印刷株式会社，2010，p. 59.

[4] 薬師寺哲郎「砂糖関連部門の波及効果と国民負 担」『農林水産政策研究』第 12 号 (2006.9), pp. 31-63.

[5]安田秀穂「自治体の経済波及効果の算出」学陽 書房, 2008.

（受理日：2012 年 5 月 25 日） 